Historia Slavorum Occidentis

2020, $\mathrm{nr} 4$ (27)

ISSN 2084-1213

DOI: $10.15804 /$ hso200409

Edward Skibiński (Poznań)

ORCID: 0000-0002-3763-6817

\title{
O źródle historycznym. Próba weryfikacji niektórych koncepcji z perspektywy źródłoznawczej
}

Słowa kluczowe: źródło historyczne, metodologia historii, semiotyka, rzeczywistość, komunikacja

Keywords: historical source, methodology of history, semiotics, reality, communication

Abstract: The article discusses the bases of the contemporary concept of the theory of sources. I have made an attempt at re-interpreting this basic concept of historical methodology based on the semiotic concept of signs and reality.

Pojęcie źródło historyczne funkcjonuje w metodyce historycznej na określenie podstawy materiałowej rekonstrukcji historycznej określanej też czasem jako synteza bądź interpretacja historyczna. Jako takie stało się też podstawą budowy antyhistorycznych teorii na gruncie rozmaitych krytyk poznania historycznego, umiejscawianych potocznie w ramach metodologii historii. Żeby odnieść się do zakresu tak rozumianego pojęcia „źródła historycznego”, odwołam się do ujęcia metodologicznego zaproponowanego przez Wojciecha Wrzoska:

Klasyczne ujęcie źródła historycznego, a więc takie, które towarzyszy klasycznej historiografii i żywiołowemu jego rozumieniu przez historyków i dominującą część źródłoznawców, przesądza, że stanowi ono, tak czy owak, swego rodzaju reprezentację rzeczywistości badanej. Nadto przyjmuje się, że „doświadczenie” rzeczywistości badanej poprzez dotarcie do niej, doznanie jej, jest wa- 
runkiem efektywnego poznania. Dowiedzieć się, jaka ona była, bo przecież była, jest podstawą tej strategii. Klasyczny historyk sądzi, że źródło historyczne pozostaje w stosownej relacji do rzeczywistości badanej, tj. takiej, że ją poświadcza. A dzieje się tak, z grubsza biorąc, ponieważ z jednej strony źródło historyczne stanowi - wedle niego - fragment jej samej (artefakty kultury materialnej czy symbolicznej świata badanego), a z drugiej jest świadectwem reprezentującym przeszłość. W pierwszym przypadku chodzi o zebranie kawałków i zbudowanie $\mathrm{z}$ nich mozaiki, $\mathrm{w}$ drugim - o dowiedzenie się via źródła, jaką ona była. W praktyce chodzi więc o lączny efekt obu tych procedur ${ }^{1}$.

Pojęcie źródła zatem w przytoczonej wyżej refleksji metodologicznej oznacza dla klasycznego historyka fragment rzeczywistości badanej, tj. minionej, z drugiej zaś ma być świadectwem reprezentującym tę rzeczywistość. Kłopotliwość korzystania $\mathrm{z}$ tak rozumianych źródeł rekonstrukcji historycznej charakteryzuje wyżej cytowany teoretyk:

Przekonanie o prawdziwości danych źródłowych nie bierze się z ich stwierdzonej zgodności z rzeczywistością samą w sobie nade wszystko dlatego, że nie da się zestawiać bytów pomyślanych, jakimi są dane źródłowe, z przedmiotowym, cielesnym czy praktycznie/zmysłowo uchwytnym światem, jakim jest, jak mniemamy, rzeczywistość historyczna. Jest ona zwykle już rzeczywistością minioną. Nie jest więc owa realność dana nam, gotowa, czekająca na konfrontację z danymi źródłowymi. Dane źródłowe mamy tu i teraz, a rzeczywistości minionej jako takiej nie mamy przed sobą².

Wojciech Wrzosek posługuje się tu mało precyzyjną terminologią - czym miałaby być „rzeczywistość sama w sobie”, czym się różni od innych rodzajów „rzeczywistości” itd. Rodzi to też inny problem - czy my/ nasi przodkowie mamy/mieliśmy rzeczywistość przed sobą. Podobnie niejasny jest termin „dane źródłowe” - jakie elementy źródła stanowią dane źródłowe, a które do niego nie należą. Nie będę jednak teraz tym się zajmował. Rozumowanie przedstawione jest wszak jasne - rekonstrukcja historyczna jest niemożliwa.

Nie jest jednak autor w myśleniu teoretycznym tylko naiwnym krytykiem metody historycznej (specyficznie rozumianej). Pisze bowiem w przypisie do powyższego tekstu tak:

1 W. Wrzosek, Źródto historyczne jako alibi realistyczne historyka, [w:] Historyk wobec źródet. Historiografia klasyczna i nowe propozycje metodologiczne, red. J. Kolbuszewska, R. Stobiecki, Łódź 2010, s. 23-38, tu s. 30.

2 Tamże, s. 32. 
Owa rzeczywistość jako taka, tj. taka, jak o niej sądzimy, że była, była „żywą, pulsującą życiem żywych ludzi”, praktyczną, widzialną, słyszalną i pachnącą. Do takiej (doświadczenia) poznania i zbadania tęskni historyk. Jej doświadczenie zakłada ujęcie ją w myśli, a więc przemianę w myśli i słowa. Te zaś są już choćby rudymentarnym jej opisem. Zestawienie danych źródłowych z nią samą może zachodzić już tylko jako zestawienie (myślowe, rzecz jasna), tych pierwszych z jej opisami. To opisy przedmiotów ustanawiają przedmioty opisów, i tylko jako takie są dostępne naszemu poznaniu. Co nie znaczy, że przedmiotem czyjegoś opisu nie może być okoliczność, że ktoś na nim usiadł, wzbogacona o kolejne opisy tegoż aktu. Korzystam tu z argumentacji J. Mitterera, Tamta strona filozofii. Przeciwko dualistycznej zasadzie poznania, Warszawa $1999^{3}$.

Zatem rysują nam się tutaj dwa problemy, jeśli pominiemy kwestię tęsknoty historyka. Ta ostatnia jest dla nas nieweryfikowalna przynajmniej w świetle tekstu W. Wrzoska. Pierwszym problemem jest cel pracy historyka, drugim zaś natura źródła historycznego, na którym badacz opiera się w swoich badaniach. Historyk jest tu określany jako historyk klasyczny. Jest to termin niezbyt udany. Nie chodzi bowiem o historyka starożytności grecko-rzymskiej - a zatem o rodzaj odpowiednika filologa klasycznego. Podstawą wydzielenia tej kategorii jest, jak wolno sądzić, koncepcja uprawiania historii, której teoretyczne podstawy wyłożył Ernst Bernheim w znanym dziele Lehrbuch der historischen Methode und der Geschichtsphilosophie ${ }^{4}$. Ostatnie wydanie tej pracy ukazało się w 1908 r., ale uczony żył jeszcze długo i zmarł w 1942 r. w nazistowskich Niemczech. Schyłkowe lata życia przyniosły mu wiele goryczy ze względu na żydowskie pochodzenie. Ani w jego losie, ani w opracowanej przez niego koncepcji nie ma nic klasycznego. W swoim dziele przedstawił bowiem wykład techniki badań historycznych, do dzisiaj stosowanej w nauce historycznej. Oczywiście użycie terminu „klasyczna historiografia” ma tu wymiar wartościujący - „klasyczna”, a więc „nienowoczesna”. Czy historyk w ujęciu teorii Bernheima dąży do rekonstrukcji „Lebensweltu”, tj. świata życia przeszłości tak, jak to imputuje mu współczesna metodologia i W. Wrzosek?

Możliwości badawcze historyka określają źródła historyczne, którymi dysponuje. E. Bernheim wydzielił dwa zasadnicze rodzaje źródeł: tradycję i pozostałości, którym odpowiadają z grubsza w wykładzie W. Wrzoska: świadectwo reprezentujące

3 Tamże.

4 E. Bernheim, Lehrbuch der historischen Methode und der Geschichtsphilosophie. Mit Nachweis der wichtigsten Quellen Und Hilfsmittel zum Studium der Geschichte, Leipzig 1908. 
przeszłość oraz fragmenty jej samej (artefakty kultury materialnej czy symbolicznej świata badanego). Błędnie jednak przedstawia W. Wrzosek zastosowanie tak rozumianych źródel, przyjmując, że w pierwszym przypadku chodzi o dowiedzenie się via źródła, jaką przeszłość reprezentują, w drugim zaś o zebranie kawałków i zbudowanie z nich mozaiki.

Pozostałości są tym, co bywa nazywane w metodyce historycznej śladem. Pisze się czasem, że źródło jako ślad donikąd nie prowadzi, bo nie ma już tego świata, którego jest śladem ${ }^{5}$ :

W wielu definicjach źródeł historycznych porównuje się je ze śladami, które zostawiła przeszłość. Nazywam takie porównanie metaforą łowiecką, gdyż po śladach myśliwy odkrywa, gdzie znajdzie zwierzę. Można by nazwać to także metaforą detektywistyczną, jako że pozostawione na miejscu przestępstwa ślady mają wieść detektywa do sprawcy tego przestępstwa.

Czy jednak tak jest z przeszłością? Czy źródło historyczne, a nawet czy wszystkie dostępne źródła historyczne prowadzą nas - tak jak myśliwego do zwierzęcia, a detektywa do sprawcy przestępstwa - do przeszłości? Nie mogą nas do przeszłości prowadzić, ta przeszłość bowiem już nie istnieje, a poza tym, gdyby istniała jako pewna całość (wszystko co w danym czasie się zdarzyło), to do takiej całości, by ją „ujrzeć” w jej pełni, żadne źródło wieść by nie mogło. Takiej całości ujrzeć (choćby metaforycznie) w ogóle nie można. Do tego potrzebne byłoby, jak to formułują niektórzy filozofowie historii, „oko Boże” (God's Eye-view). Nawet gdyby chodziło o niewielki jej fragment.

Przytoczony wyżej fragment pochodzi z Wprowadzenia do historii Jerzego Topolskiego, jest jednak również charakterystyczny dla współczesnej teorii historii. Taka argumentacja na temat źródeł historycznych polega jednak na nieporozumieniu. Żeby to objaśnić, sięgnijmy do doświadczenia potocznego. Opowiadając o powrocie z wakacji, odnosimy się do chwili, która przeminęła. Również sytuacje, w których uczestniczyliśmy, już nie istnieją. Podobnie przestępstwo popełnione przed rokiem już nie istnieje. Jakiż zatem powód trzymania przestępcy w więzieniu? I czy jest on przestępcą w rok po dokonaniu przestępstwa, czy tylko w chwili jego wykonywania? Te problemy dawno już stały się podstawą opracowania koanów zen. Jednak poza takimi eksperymentami myślowymi na ogół nikt nie podważa naszych możliwości mówienia o świecie, w którym żyjemy. To, o czym opowiadamy, czy to, czego dociekamy, to nie jest cała rzeczywistość czy cała prawda w sensie dosłownym. Choć czasem tak mówimy,

5 J. Topolski, Wprowadzenie do historii, Poznań 2001, s. 36 i nn. 
mamy jednak na myśli coś innego. Człowiek zdradzony czy oszukany chce wiedzieć, kto zawinił, policja chce dociec, kto popełnił przestępstwo. Wszystkie inne aspekty rzeczywistości, o których mamy świadectwa, są ważne tylko w tym zakresie, w jakim pozwalają odpowiedzieć na najważniejsze pytanie. Jeśli np. sfilmowano to, co się zdarzyło, to dla policji ważne są tylko te elementy, które poświadczają czyjeś przestępstwo.

Problematyka ta jednak jest bardziej złożona i wymaga innego objaśnienia. Zacznijmy zatem od źródeł historycznych jako pozostałości. Czym jest pozostałość? Jest rzeczywiście elementem, który uprzednio należał do większej całości, do której obecnie odnosi się w jakiś sposób, który można określić jako znakowy. Jest zatem pewnym przedmiotem znaczącym - znakiem, wskazującym na swój przedmiot który już nie istnieje.

Dobrze to rozpoznała Teresa Kostyrko, wskazując, że pojęcie źródła historycznego można łatwiej objaśnić, gdy zaakceptujemy jego znakowy charakter ${ }^{6}$. Posłużyła się jednak specyficzną, wypracowaną - jak się można domyślać - w pracach Jerzego Kmity, koncepcją znaku:

Wspólną dla tych koncepcji źródła jest zasada ich podziału, który można przedstawić jako podział na:

- zjawiska czy stany rzeczy będące przedmiotem badań historyka z uwagi na to, że stanowią oznakę stanów rzeczy minionych (często dla określenia tych zjawisk używa się pojęcia śladu);

- zjawiska będące przedmiotem badań historyka z uwagi na to, że są one znakami, ściślej mówiąc są rozpatrywane z uwagi na ich cel komunikacyjny. Źródło rozpatrywane $\mathrm{z}$ uwagi na ten cel często nazywane jest w literaturze historycznej „świadectwem”.

Koncepcja T. Kostyrko zdaje się dobrze pasować do schematów podziału źródeł, które znamy z podręczników historyki. Ma jednak wady. Koncepcja źródła jako oznaki stanów minionych naraża się na krytykę sformułowaną m.in. przez W. Wrzoska. Źródło jako „oznaka stanów rzeczy minionych” jest postulatem zbyt szerokim, choć może w pewnej mierze spełnialnym. Trzeba jednak przeformułować tę koncepcję, żeby mogła być brana pod uwagę w dyskusji na temat źródeł historycznych. Taka koncepcja znaku, jaką zaproponowała T. Kostyrko, wywodzi się, jak

6 T. Kostyrko, O pojęciu źródła historycznego. Na marginesie giedyminowej krytyki koncepcji E. Bernheima, [w:] O nauce i filozofii nauki. Księga poświęcona pamięci Jerzego Giedymina, red. K. Zamiara, Poznań 1995, s. 81 i nn.

7 Tamże, s. 81. 
już wspomniałem, z prac J. Kmity. Spróbuję to teraz objaśnić. W swojej koncepcji filozoficznej czynności ludzkich używał on pary terminów znak - oznaka na oznaczenie określonych rodzajów zachowań czy stanów znaczących. Nie odnosił się jednak poznański filozof do zagadnień semiotyki. Jego koncepcja znaczenia nie wyczerpuje problematyki teorii znaku nawet w ramach jego poglądów filozoficznych. Zastosowanie jej w roli zamiennika semiotyki, jako ogólnej teorii znaku, prowadzi jednak na manowce. Słowo semiotyka oznacza wszelkie zagadnienia dotyczące problematyki znaków. Semeiotikos to w pewnym uproszczeniu po prostu znakowy, od semeion - znak. Jednak semiotyka jako określenie pewnej dziedziny badawczej wymaga doprecyzowania. Pomoże nam to odpowiedzieć na pytanie, jak można ująć pozostałość jako znak. Semiotyka jako teoria znaku jest koncepcją amerykańskiego teoretyka Charlesa S. Peirce’a, rozwijaną następnie przez jednych jego następców (Max Bense i jego szkoła) i upraszczaną przez innych (Charles W. Morris). Te różne odmiany teoretyczne znacznie utrudniają orientację w problematyce znaku. Dodać należy do tego koncepcje językoznawcy Ferdinanda de Saussure’a recypowane następnie przez teoretyków francuskich. Różni inni teoretycy używali tego terminu w znaczeniu ogólnym stosownie do swoich potrzeb - np. Jurij Łotman, Umberto Eco itd. Termin znak w klasycznym ujęciu oznacza relację łączącą trzy człony - środek przekazu, przedmiot znaku i znaczenie. Ch.S. Peirce określa te trzy człony, zgodnie z amerykańską metodą, którą widać m.in. w nazwach ulic, przy pomocy numerów - jako pierwsze, drugie i trzecie. Znak jako środek przekazu zastępuje swój przedmiot: „Znak lub reprezentamen jest czymś, co dla kogoś zastępuje coś innego pod pewnym względem lub w pewnej roli ${ }^{8 ”}$. „Znak zastępuje coś, mianowicie swój przedmiot. Zastępuje ten przedmiot nie pod każdym względem, ale w odniesieniu do pewnego rodzaju idei. Którą czasami nazywałem reprezentamen"”.

Znak jest więc triadą - trójczłonowym związkiem łączącym środek przekazu, przedmiot i znaczenie. Są to określenia przejęte z filozofii antycznej. Odpowiadają im monada, diada i triada ${ }^{10}$. Znaczenie ujmuje relację, jaka łączy środek przekazu i przedmiot znaku. Jest też innym znakiem. Znak zatem nie występuje sam, niezależnie od innych. Bez innych znaków nie mógłby funkcjonować, nie miałby znaczenia. Znak zastępuje przedmiot pod pewnym względem - ale go nie wytwarza. „Pierwszym”, czyli

8 H. Buczyńska-Garewicz, Semiotyka Peirce'a, Warszawa 1994, s. 43; Ch.S. Peirce, Wybór pism semiotycznych, red. H. Buczyńska-Garewicz, Warszawa 1991, s. 131.

9 Ch.S. Peirce, Wybór pism semiotycznych, s. 131.

10 H. Buczyńska-Garewicz, Semiotyka Peirce'a, s. 45. 
środkiem przekazu mogą być jakości, rzeczy lub idee ogólne. „Pierwsze” nazywamy z łacińska - reprezentamen. „Pierwsze” może być w stosunku do drugiego, czyli swojego obiektu, ikonem, indeksem lub symbolem. Jako ikon odnosi się do jego cech zewnętrznych. Indeks jest indywidualnym (pojedynczym) drugim - czyli obiektem. Symbol jest znakiem umownym ${ }^{11}$.

Czym jest zatem pozostałość, jeśli zastosować do jej objaśnienia tak rozumianą teorię znaku? W terminologii semiotyki chodzi tu o formę relacji pierwszego - czyli nośnika znaczenia do swojego obiektu. Określamy tę formę terminem indeks wskaźnik. Jak można się jednak odnieść do nieistniejącego już przedmiotu? A wiemy, że z taką sytuacją mamy do czynienia w przypadku źródeł historycznych. Jak już wskazałem, jest to zjawisko dosyć częste - ale jak je objaśnić? W myśli francuskiej teoretycy posługują się zwykle dwudzielną koncepcją znaku, wyróżniamy mianowicie „znaczące”, tj. materialną stronę znaku, i „znaczone”: jeśli weźmiemy wyraz „kot”, to znaczącym będzie jego obraz akustyczny, natomiast znaczeniem - pojęcie „kota”. Jest to koncepcja zaproponowana przez F. de Saussure’a w jego sławnym, wydanym pośmiertnie na podstawie notatek uczniów Kursie językoznawstwa ogólnego ${ }^{12}$. Taka koncepcja nie oddaje jednak dobrze problematyki znaczenia. Lepszą przedstawił Ch.S. Peirce. Znak jest według niego trójdzielny. Obok pierwszego, który jest odpowiednikiem znaczonego i reprezentuje znak na zewnątrz, wydzielił jeszcze drugie - odniesienie przedmiotowe znaku - $\mathrm{i}$ trzecie - znaczenie znaku, zwane tu interpretantem, które ujmuje przedmiot znaku pod pewnym względem. Wyróżnienie odniesienia przedmiotowego i znaczenia pozwala uchwycić całość relacji znakowych. Tak jest również z indeksami, które odsyłają do swoich przedmiotów za pomocą symbolu, tj. swojego interpretanta. Ten ostatni termin oznacza inny znak, który określa jego znaczenie. Znak tak rozumiany jest bytem obiektywnym w tym sensie, że jest niezależny od naszej indywidualnej woli - stawia jej opór. Nie mamy tu też do czynienia z relacjami psychologicznymi, lecz semiotycznymi, tj. znakowymi. Źródło historyczne jest oczywiście również znakiem i jest to jego określenie podstawowe. Wszystkie inne muszą być nadbudowane nad nim. Jako reprezentamen, czyli w swojej podstawie materialnej, źródło odnosi się do swojego obiektu, którym są przeszłe zdarzenia, stany rzeczy itd. tak, jak znaki do swego obiektu. Może być zatem ikoniczne, indeksowe, symboliczne. Źródła indeksowe nazywamy pozostałościami.

11 Ch.S. Peirce, Sundry logical conceptions, [w: ] The essential Peirce. Selected philosophical writings, Vol. 2 (1893-1913), Bloomington-Indianapolis 1998, s. 265-288, tu s. 274.

12 M. Danielewiczowa, Dosięgnąć przedmiotu. Rzecz o Ferdynandzie de Saussurze, Warszawa 2016, s. 146 i nn. 
Jeśli potraktujemy ślad jako indeks - co to właściwie znaczy? Weźmy za Peirce’em przykład z Robinsona Crusoe, który zobaczył ślad stopy na piasku ${ }^{13}$. Jak pokażę, mamy tu pełne odniesienie przedmiotowe. Znak ten jest ikonem - jest odciskiem stopy, jest też indeksem, pozostałym po działaniach i odsyłającym do istoty żywej, która ten ślad pozostawiła - oraz symbolem - symbolizuje bowiem istotę ludzką. Przyjrzyjmy się „pierwszemu” znakowi - czyli jego nośnikowi: co jest środkiem przekazu w omawianym przykładzie? Najpierw należy wskazać na sypkość piasku, która sprawia, że możemy za znaczące uznać jakość - w terminologii amerykańskiego filozofa jest to qualisignum. Jednak nie wyczerpuje to naszej problematyki. Co sprawiło, że odciśnięcie się śladu stopy było możliwe? Jest to pewna możliwość, którą stwarza piasek - zwana sensisignum. Ogólna jakość zaprowadziła nas zatem do pewnego zdarzenia, które otrzymuje konwencjonalną nazwę ogólną określaną jako legisignum. Do interpretacji potrzebujemy materiału porównawczego, czyli znajomości śladów innych ludzi. Zestawienie ich z konkretnym odciskiem powoduje interpretację dicentyczną. Wszystko, co łączy Robinsona jako interpretanta zewnętrznego ze śladem, byłoby jego interpretacją całkowitą.

Są jeszcze dwie inne formy znakowego odniesienia do przedmiotu - ikon i symbol. Zaproponowałem kiedyś podział źródeł na digitalne i analogowe. Digitalne źródła są to komunikaty zakodowane - np. sformułowane w jakimś języku - z kolei analogowe używają do kodowania pewnych cech przejętych od swego przedmiotu. Odpowiada to podziałowi stosowanemu w semiotyce na znaki ikoniczne i symboliczne. Podział ten, będący tylko elementem semiotycznej analizy znaku, jest ważny dla pojęcia źródła historycznego. Jest ono bowiem znakiem wyróżnianym przez swoje odniesienie przedmiotowe. Źródło ikoniczne odnosi się do swojego przedmiotu na mocy podobieństwa - czyli pod względem formy - indeksowe na mocy łączności przedmiotowej ze wskazywanym przedmiotem, symboliczne przez zakodowaną informację. To odniesienie wyraża się w znaczeniu źródła. Znaczenie ujmuje przedmiot znaku tylko pod pewnym określonym względem. Nigdy jako całość. Jednocześnie jednak samo znaczenie jest również znakiem i jako takie tworzy ciągi, które budują większe całości, łącząc stany, do których się odnoszą ostatecznie, w coś, co możemy nazwać tekstami kultury - całościami semiotycznymi wyższego rzędu. Należy jednak pamiętać, że te wytwory nie tworzą spójnych całości, lecz jedynie fragmentaryczne. Ta fragmentaryczność tworzy całość jedynie w odniesieniu do świata realnego, który jawi się w naszym postrzeże-

13 M. Bense, Świat przez pryzmat znaku, thum. J. Garewicz, Warszawa 1980, s. 129 i nn.; Ch.S. Peirce, Prolegomena to an apology for pragmaticism, The Monist 16 (1906), s. 492-546, tu s. 496 inn. 
niu. Takie semiotyczne całości stanowiące modele rzeczywistości nie wyczerpują tej ostatniej. Nie są też tworami trwałymi. Podlegają modyfikacji wraz ze zmieniającym się światem, do którego się odnoszą. Świat przedstawień i świat postrzegany tworzą całości semiotyczne połączone sprzężeniem zwrotnym. Są też zasadniczymi elementami naszego świata komunikacji.

Znak zastępuje swój przedmiot, jednak nie w całości, a tylko w pewnym jego aspekcie. Przedmiot jest rzeczywisty, tj. nie może być zmieniony przez użytkownika znaku. Nie oznacza to jednak, że nie może to być przedmiot abstrakcyjny - takim może być np. liczba. Pojęcie źródła historycznego opiera się intuicyjnie na pojęciu znaku. Podział odniesień na indeksowe, ikoniczne i symboliczne jest też podstawowym podziałem źródeł historycznych. Jak widać, nie są to podziały dowolne. Dopiero nad tym podziałem można budować następne. Również ten zaproponowany przez Gerarda Labudę. Dokładnie natomiast odpowiada mu podział E. Bernheima na tradycję i pozostałości ${ }^{14}$. Rozróżnienie tradycji na obrazową, ustną i pisemną oparte jest na sposobie kodowania przekazywanych w ten sposób komunikatów. Jednak kodowanie w mowie ustnej i pisemnej jest oparte na tej samej zasadzie kodu symbolicznego czy digitalnego.

Odnieść się wypada również do innej części poglądów W. Wrzoska na temat badań historycznych. Pisze on mianowicie: „Procedury weryfikujące dane źródłowe zestawiają je nie z rzeczywistością samą w sobie, lecz z realnością ustanowioną przez dotychczasowe narracje historyczne, przez zastaną wiedzę historyczną" ${ }^{15}$. Czym jest ta zastana wiedza historyczna? Zdaniem W. Wrzoska:

Ta zastana historyczna wiedza o okolicznościach, zjawiskach, zdarzeniach czy ludziach wyznacza wymiary realności, „rodzaj i jakość realizmu” przyjmowanego przez historyków. W rezultacie polem odniesienia w procedurze danych źródłowych jest wspólnotowa wiedza historyków, ustanawiająca, co może się znajdować w danej domenie „historycznej prawdziwości” ${ }^{16}$.

Jak to jest zatem z tym ustanawianiem? Analizowany autor pisze o tym tak:

Podobnie profesjonalny ogląd przeszłości bierze się nie tyle z faktu nabycia zdolności do wglądu w rzeczywistość samą w sobie, poprzez skuteczne władanie

14 W sprawie podziału E. Bernheima patrz: A. Kuligowska, Koncepcja źródła historycznego Ernsta Bernheima w "Lehrbuch der historischen Methode und der Geschichtsphilosophie”, „Historyka. Studia Metodologiczne” 39 (2009), s. 30-31.

15 W. Wrzosek, Źródto historyczne jako alibi, s. 32.

16 Tamże, s. 33. 
instrumentami docierania do niej, ile z opanowania uznawanych przez wspólnotę reguł prowadzenia badań i sporządzania narracji badawczej. Śladem tradycji opowiadania kontynuujemy opowieść na miarę dzisiaj stawianych pytań. Powtórzmy, to koledzy badacze decydują o tym, czy zaprezentowana przez nas wizja przeszłości ma cechy uprawniające ją do bycia produktem historiograficznym, w tym wytworem akademickiej historii ${ }^{17}$.

Mamy tu poruszone dwa różne problemy. Pierwszym jest funkcjonowanie określonego dyskursu naukowego posługującego się własnym systemem kategorii i językiem opisu badanych zjawisk. Historyk, żeby móc komunikować się z innymi, musi używać języka, którym inni się posługują. Komunikowanie wyników badań czy wymiana poglądów są możliwe tylko w taki sposób. Język naturalny, którym się posługujemy w sposób oczywisty, nakłada na nas okulary, przez które postrzegamy rzeczywistość. Można też powiedzieć, że mając na nosie okulary, tak naprawdę widzę tylko ich szkła. Trudno jednak zaakceptować taki sąd. Większość nakłada okulary, żeby lepiej widzieć świat, który nas otacza.

\section{Typy źródeł}

Pojęcie źródła historycznego ma swoją podstawę, jak to wcześniej wykazałem, w teorii znaku wypracowanej na gruncie semiotyki. Zostało ono jednak wyprowadzone niezależnie od tej koncepcji w toku badań H.A. Erharda i E. Bernheima, jak to w swojej pracy pokazała Aleksandra Kuligowska ${ }^{18}$. Zbieżność obu koncepcji pozwala je traktować jako opisy wzajemnie się dopełniające, przy tym semiotyka byłaby teorią ogólną, teoria źródła historycznego zaś jej szczególnym zastosowaniem. Podstawą wyróżnienia źródła historycznego byłby zatem jego znakowy charakter. Znak jako reprezentamen jest czymś, co dla kogoś zastępuje coś innego pod pewnym względem. Definicja E. Bernheima w tłumaczeniu A. Kuligowskiej przynosi takie określenie źródła historycznego: „źródła są [takimi] rezultatami działalności ludzkiej, które jako pierwotnie określone, bądź też poprzez ich egzystencję, powstanie i inne wyróżnione stosunki, szczególnie się nadają do poznania i do dowodzenia historycznych faktów” ${ }^{\prime 19}$. Źródło historyczne jest więc znakiem. Już w tej definicji widać, że kładzie ona nacisk na wskaźnikowy (indeksowy) charakter źródła jako

17 Tenże, O myśleniu historycznym, Bydgoszcz 2009, s. 10.

18 A. Kuligowska, Koncepcja źródła historycznego Ernsta Bernheima, s. 21-41.

19 Taż, Auffassung w koncepcji Ernsta Bernheima, Poznań 2013, s. 91. 
znaku. Jak się ma zatem podział znaku Ch.S. Perice’a na wskaźnik, symbol i znak ikoniczny do podziału źródeł E. Bernheima na tradycję i pozostałości? Ponieważ pojęcie tradycji jest w miarę zrozumiałe, skoncentrujmy się na drugim terminie w Bernheimowskim podziale - na pozostałościach. A. Kuligowska tak to objaśnia w swojej monografii:

Przyjmując takie założenie dzieli Bernheim Überreste na pozostałości w ścisłym znaczeniu - inaczej zabytki (Überreste im engeren Sinne - Überbleibsel), które z przeznaczenia nie mają być kierowane do potomności jako upamiętnienie przeszłości oraz pomniki. Jak widać w wyżej przedstawionym schemacie tego podziału, do pozostałości w ścisłym znaczeniu zaliczać się będą zarówno szczątki ciała ludzkiego (których wedle G. Labudy nie ma w klasyfikacji Bernheima), jak i typowe dla tej grupy i przedmioty drobne (monety, dzbanki), i większych rozmiarów na przykład budowle, bardziej może kojarzone z zabytkami. Po drugiej stronie umieścił Bernheim pomniki, czyli tego rodzaju artefakty, których pierwotnym przeznaczeniem było upamiętnianie przeszłości. Do tej kategorii zaliczył też dokumenty, spisane w celu stwierdzenia i uregulowania stosunków prawnych, dalej epigrafikę - wyłączając napisy wchodzące w zakres tradycji mającą upamiętniać określone osobistości przy osobistym ich zainteresowaniu oraz ważne zdarzenia. Te same cele realizowane są przez posągi, a więc pomniki w ścisłym znaczeniu. Poszczególne elementy podzbioru „pozostałość” łączą się również z podzbiorami „tradycji”, gdyż mogą prezentować pewne wyobrażenie treści, które wchodzi w zakres poznania pośredniego. Należy jednak dodać, że wszystko, co w źródle typowe, wchodzi w zakres pozostałości. Dlatego dokument, którym zajmuje się dyplomatyka, z całym jego formularzem będzie źródłem bezpośrednim. $\mathrm{O}$ wiele jaśniej przedstawia się podział tradycji, którą podzielił Bernheim na pisemną, ustną i obrazową, a zatem w zależności od środka przekazu ${ }^{20}$.

Termin pozostałości na gruncie semiotyki ma odpowiednik w pojęciu wskaźnika - indeksu. Termin ten, jak i cały ten podział, jest wydzielony ze względu na odniesienie znaku do swojego przedmiotu: „Znak może być powiązany z przedmiotem w trojaki sposób: może być znakiem ikonicznym, wskaźnikiem lub symbolem. Każdy z tych sposobów jest innym typem związku: pierwszy jest związkiem przez podobieństwo, drugi jest faktyczną, materialną zależnością, trzeci jest wreszcie związkiem konwencjonalnym, czyli idealnym związkiem opartym na prawie”21.

20 Tamże, s. 98.

21 H. Buczyńska-Garewicz, Semiotyka Peirce'a, s. 63. 
Przyjrzyjmy się zatem koncepcji wskaźnika w semiotyce Ch.S. Peirce’a, pamiętając, że na gruncie historyki E. Bernheima odpowiada mu pojęcie pozostałości. Pisze o tym amerykański filozof tak:

„Wskaźnik jest to” znak czy reprezentacja, która odnosi się do swego przedmiotu nie ze względu na podobieństwo czy analogię i nie ze względu na skojarzenie z ogólnymi cechami, jakie przedmiot posiada, ale z tego względu, że ma - z jednej strony - dynamiczny ( $w$ tym także przestrzenny) związek z indywidualnym przedmiotem, a z drugiej strony - z wrażeniami czy pamięcią osoby, której służy jako znak. Nie można stwierdzić faktu bez użycia znaków służących jako wskaźniki ${ }^{22}$.

Użyte tu pojęcie - przedmiot - nie ma znaczenia wyłącznie rzeczowego, należy je rozumieć tak jak w zwrocie „przedmiot poznania”. Ta dynamiczna łączność z przedmiotem występuje również w pojęciu pozostałości. Czy wskaźnik nie może być również znakiem ikonicznym i symbolem? Przypomnijmy rozróżnienie Ch.S. Peirce’a na przykładzie opowieści o Robinsonie Crusoe, który zobaczył ślad stopy na piasku ${ }^{23}$. Znak ten jest znakiem ikonicznym stopy, jest też indeksem, pozostałym po działaniach i odsyłającym do istoty żywej, która ten ślad pozostawiła, oraz symbolem - symbolizuje bowiem dla Robinsona istotę ludzką. Jak to jest z pozostałością?

Jak wskazuje A. Kuligowska, Ernst Bernheim wyróżniał trzy rodzaje interpretacji historycznej:

1. Interpretation der Überreste.

2. Interpretation der Tradition.

3. Interpretation der Quellen durch einander ${ }^{24}$.

Czym są pozostałości, które są uwzględniane w interpretacji historycznej? Weźmy za przykład tekst pisany. Pisze A. Kuligowska o tym tak:

Jak już wskazywałam, dukt pisma, zgodnie z podziałem Bernheima, traktowany będzie jako pozostałość. Wszelkiego rodzaju znaki, na przykład korektorskie, interpunkcyjne i inne, mogą mieć jednak również symboliczne znaczenie. Bernheim podał jako przykład znaczenie przekreśleń: przekreślone nazwisko

\footnotetext{
22 Ch.S. Peirce, Wybór pism semiotycznych, tłum. R. Mirek, A.J. Nowak, Warszawa 1997, s. 163.

23 M. Bense, Świat przez pryzmat znaku, s. 129 i nn.; Ch.S. Peirce, Prolegomena to an apology, s. $496 \mathrm{i} \mathrm{nn}$.

24 Tamże, s. 170.
} 
w księdze rachunkowej może oznaczać uregulowanie długu, a na liście rycerzy wzywanych do królewskiej straży przybocznej odpowiedź odmowną 25 .

I dalej:

Jednym z podstawowych problemów związanych z rozumieniem autora jest rozpoznanie jego indywidualnego zwyczaju językowego, który różni się w zależności od czasów, z jakich pochodzi tekst. Obyczaj językowy, wyrażany choćby w wielokrotnym użyciu pewnych określonych terminów, kategorii lub formuł językowych, da się wedle Bernheima, ustalić na przykład za pomocą statystyki. Wyznaczenie ich pozwala nam je ująć w innym ich aspekcie - jako pozostałości po działalności autora ${ }^{26}$.

Niedoceniany przez historyków aspekt źródła jako pozostałości ciągle jeszcze jest koncepcją nowatorską. Pojęcie pozostałości odwołuje się do czynności, które powołały artefakt - ujmowany przez nas jako źródło - do istnienia.

Czym jest zatem taka interpretacja znakowa, którą stosujemy w historii i określamy jako interpretację tradycji i pozostałości? Z Berheimowskiego podziału na tradycję obrazową, ustną i pisaną pozostawimy tylko podział dwuczłonowy. W semiotyce byłyby to aspekty ikoniczny i symboliczny - w źródłoznawstwie, jak proponowałem, analogowy i digitalny. Stosując oba te pojęcia, odwołuję się do rodzaju użytego kodu analogowego bądź digitalnego. Samo odwołanie do kodowania oznacza, że komunikat zawarty w źródle, składający się na jego znaczenie, rozumiemy jako zbudowany na bazie pewnego rodzaju reguł obowiązujących w procesie komunikacji - nadawca podporządkował się im w celu przekazania komunikatu. Sfera, do której te reguły należą, może być określona jako symboliczna. Jednak komunikowanie wymaga też rozpoznania treści w odniesieniu do konkretnej rzeczywistości, do której komunikat się odnosi - tę sferę określmy jako semantyczną. Jest ona powiązana z imaginacyjną - z wyobrażeniami występującymi przy konkretnym odniesieniu do mowy. Dopiero trzecia sfera przynosi odniesienia realne - przez zaburzenie formy symbolicznej. Weźmy dla przykładu obraz przedstawiający scenę biblijną. Sferę symboliczną będzie reprezentowało wszystko, co teologiczne, zgodne z regułami autorytetu, jakim w tym wypadku był Kościół w osobach konkretnych decydentów, którzy przyjmowali pewien zespół reguł. Odniesienie namalowanej postaci do realnie znanej odbiorcom obrazu osoby nie naruszy sfery symbolicznej, dobuduje jej jednak nowy wymiar. Tak samo będą działały prezentacje innych postaci, np. uczestniczących

25 Tamże, s. 176-177.

26 Tamże, s. 183. 
w scenach pasyjnych. Elementem innego rodzaju będzie rama obrazu wyznaczająca granice obu światów, ale też wyznaczająca relacje komunikacyjne między obu światami - obrazu i jego odbiorcy. W tym sensie może być też rozumiany kodeks przedstawiający całość, która powstawała stopniowo przez dziesiątki lat. Całość tego rodzaju była komunikatem, z którym podjęto dalszy dialog. Przy tym obowiązuje tu zasada komunikacji Palo Alto - nie można nie komunikować - każde „wejście” ma znaczenie repliki dialogowej.

Komunikacja na poziomie symbolicznym nie zawsze musi odpowiadać realnej semantyce całości. Również odbiór tej całości podlegał i podlega podobnym regułom. Badacz narzucał całości zgodne z przyjmowanymi w odbiorze zasadami znaczenie, które przy badaniu strony semantycznej czy imaginacyjnej jest nie do utrzymania. Podsumowując, możemy mówić o dwóch podejściach. Jednym, rozumiejącym badany artefakt jako całość stającą się w procesie historii (Brygida Kürbis), i drugim, badającym gotowy obiekt.

Pierwsze podejście, traktujące źródła jako ślady, musi polegać na rekonstrukcji tych faktów historycznych, do których ciągu należały (historiografia genetyczna). Badanie tradycji kodowanej analogowo i cyfrowo (digitalnie) wymaga rozpoznania kodu na każdym poziomie jego funkcjonowania. Odniesienie jednak do pojedynczej sytuacji zbliża nas do wyników osiągniętych w pierwszym podejściu.

Wszelka komunikacja posługuje się komunikatami, którym przydziela określoną formę. Również całości komunikacyjne bardziej złożone realizują tylko pewne formy złożeń, odrzucając inne. Sprawia to, że poza regułami kodowania mamy jeszcze reguły tworzenia komunikatów na każdym ich poziomie. Przy tym treści ideologiczne/symboliczne - budowane zgodnie z regułami przekazu symbolicznego narzucanymi z zewnątrz - mogą być realizowane przy pomocy różnego rodzaju kodowań. Można to najłatwiej dostrzec w malowidłach, gdzie prezentacja świętości bądź cierpienia może być nieczytelna dla posługujących się innymi regułami odbiorców. Podobnie jak nie wszystkie możliwości formalne są realizowane w procesie komunikacji, tak również nie wszystkie możliwe treści są komunikowane. $Z$ drugiej jednak strony należy w tego rodzaju analizach uwzględnić kongenialność wypracowaną na gruncie teorii E. Bernheima. Opowieści o zdarzeniach, świat naszych wyobrażeń są również regulowane możliwościami wyznaczonymi nam przez biologię - występowanie analogicznych schematów w różnych kulturach może być tym spowodowane niejako oddolnie. Zatem wszystkie opowieści o relacjach międzyludzkich mogą wykazywać podobieństwa nieuwarunkowane przez historyczną wspólnotę kodów symbolicznych. Z drugiej zaś strony rozważa się wpływ wspólnych podstaw odno- 
szących się do pracy mózgu na gruncie współczesnej neurosemiotyki. Świadome wydzielanie tych warstw $\mathrm{w}$ podejmowanych analizach pojawia się rzadko. W rozważaniach na temat newsów prasowych podjęto ten temat. Komunikacja monologiczna i dialogiczna będą się różniły. Używa się tu czasem pojęcia kultury zorientowanej na treść lub na wyrażenie ${ }^{27}$. W tej pierwszej właściwe przekazanie nowych wiadomości będzie celem podejmowania działań komunikacyjnych, w drugiej będzie nim potwierdzenie niezmiennej prawdy. Różny jest tu schemat komunikacji. Gdyby kody nadawcy i odbiorcy były tożsame, mogliby oni wymieniać się tylko takimi informacjami, które można wyrazić w danym języku ${ }^{28}$. Przekazanie nowych informacji wymaga zmiany kodu. Jak wiemy, nasza metafizyka wiele zawdzięcza strukturze języków indoeuropejskich. Naturalne jest to, co układa się w sposób analogiczny do naszych wypowiedzi. Nie będę się jednak teraz zagłębiał w te zagadnienia. Ze względu na wprowadzający charakter artykułu przedstawiłem tu tylko przykładowo kilka podstawowych zagadnień, które wymagałyby uwzględnienia w dyskusji na temat podstaw badań historycznych.

\section{Znak a komunikat}

Źródło jest rodzajem znaku, który możemy określić jako pewną całość komunikacyjną. Jako źródło jest dla nas komunikatem/tekstem z dominującym odniesieniem przedmiotowym. Komunikat jako forma przekazu musi się najpierw oddzielać od innych komunikatów w porządku przekazu i od nie-komunikatów, tj. tego, co nie ma wartości znakowej - musi mieć granicę. Ta granica jest swoistą ramą komunikacyjną pozwalającą interpretować komunikat jako pewną całość. Oddzielanie się od nie-komunikatów oznacza wydzielenie świata znaków ze świata przedmiotowego, a co za tym idzie - funkcji rzeczowej od semiotycznej.

Jako rzecz źródło jest śladem, pozostałością w historyce, jako tekst jest komunikatem w teorii komunikacji. Funkcja rzeczowa przedmiotu wyznaczona jest jednak w ramach semiosfery - forma narzędzia pozwala na jego odpowiednie użycie, pozwala też rozpoznać, jakiego narzędzia mamy użyć. Funkcja rzeczowa więc wyznaczana jest w ramach uniwersum semiotycznego, należy do naszego porządkowania świata - parafrazując neopozytywistów: znaczeniem rzeczy jest jej użycie.

27 J. Łotman, B. Uspienski, O semiotycznym mechanizmie kultury, tłum. J. Faryno, [w:] Semiotyka kultury, wybór i oprac. E. Janus, M.R. Mayenowa, Warszawa 1975, s. 186-187.

28 J. Łotman, Kultura i eksplozja, tłum. B. Żyłko, Warszawa 1999, s. 31 i nn. 
Komunikując, posługujemy się komunikatami. Wedle zastosowanego typu kodu wyróżniamy komunikaty analogowe i digitalne. Są to jednak tylko typy idealne. W praktyce stosujemy obie formy. Każdy komunikat możemy rozpatrywać jako znak - jednak jest on również zbudowany ze znaków. Tak rozumiany komunikat jest tworem złożonym - tekstem. Tworzy jakby barwną tkaninę, którą w pewnym stopniu możemy rozpatrywać jako samodzielną całość. Z drugiej strony, badając jej wiązania, użyte nici, spójność, postępujemy jak badacz analizujący koherencję tekstu. Te komplikacje można uchwycić również na wyższym poziomie. Tekst jako komunikat jest elementem większej całości osiągającej w dobie elektronicznych środków komunikacji duży stopień komplikacji.

Ślad/pozostałość jest tym, z czym mamy bezpośrednio do czynienia. Ślad jako komunikat musi mieć formę, która opiera się na podobieństwie ikonicznym. Od strony formalnej mamy zatem tylko źródła digitalne i ikoniczne. Jeśli źródło jest artefaktem, to ma też pewną funkcję rzeczową, którą możemy (nie zawsze) odczytać.

Komunikat, którym jest źródło historyczne, może być zatem odczytany. Pełniejsze zrozumienie takiego przekazu wymaga jednak wejścia głębiej - w badanie form komunikacji minionych epok. Formy te, jakkolwiek zbieżne na poziomie komunikacji interpersonalnej, nie osiągały takiego poziomu komplikacji jak dzisiaj - na poziomie komunikacji masowej. Jednak od tysięcy lat wykazują ciągłość rozwoju - świat dzisiejszy wyrasta z wczorajszego. Przeszłość zawiera klucze do przyszłości.

Wątpliwości zgłoszone przez Topolskiego, a potem Wrzoska winny być skierowane o jeden poziom wyżej - jeżeli źródła/teksty nie mogą mówić o rzeczywistości, to czym jest ta rzeczywistość? U obu teoretyków rzeczywistość zdaje się czymś odrębnym od naszych komunikatów i przez to działającym w innej sferze, a nie na innym poziomie. Klasyczna historiografia przyjmuje natomiast pogląd, że tekst i rzeczywistość różnią się poziomem semantycznym - należą jednak jednocześnie do tego samego uniwersum znaków. Tekstem dla nas jest zarówno dokument, jak i zachowanie, strój itd. To, co robimy, jest też tekstualizowane przez duchownych, polityków, prawników. Podobnie rzeczywistość jest naszym społecznym wytworem i zmienia się, co widzieli ci, którzy przeżyli przejście od PRL do III i IV RP. W tym sensie ma ona charakter dyskursywny. Język zapachów, przeważnie przecież sztucznych, jest dobrym przykładem na wytwarzanie przez nas rzeczywistości. Ta rzeczywistość bez nas nie istnieje. Historyk natomiast zajmuje się ludzką rzeczywistością, to znaczy światem zinterpretowanym przez człowieka i poddanym kolejnym reinterpretacjom. Dzięki temu taką rzeczywistość można badać, poddawać krytyce i zmieniać, tak jak to robi np. terapeuta. 
Ten relatywizm nie oznacza jednak dowolności. Paranoja systemu totalitarnego opisana przez George’a Orwella w Roku 1984 ma klęskę wpisaną w system (choć czasem trzeba na nią długo czekać), ponieważ świat nie może funkcjonować, nie mając kontaktu ze swoją semiotyczną rzeczywistością. Zadaniem historyka jest badanie takiego właśnie wielopoziomowego semiotycznego świata przeszłości w zakresie, w jakim teksty owego świata są dla nas dostępne.

Nadesłany: 6 VI 2020

Nadesłany po poprawkach redakcyjnych: 21 IX 2020

Zaakceptowany: 27 IX 2020

prof. UAM dr hab. Edward Skibiński

Uniwersytet im. Adama Mickiewicza w Poznaniu

Wydział Historii

ul. Uniwersytetu Poznańskiego 7

61-614 Poznań

e-mail: edward_skibinski@yahoo.com

\section{Summary}

In this article I analyse the critical concept of a historical source as interpreted in the contemporary theory of history (W. Wrzosek). I have also provided a critique of the theory by re-interpreting the methodological concept of a historical source and the division thereof based on the semiotic concept of signs and reality formulated by Ch.S. Peirce. Next, I have analysed the concept of historical reality by indicating its semiotic nature. Consequently, I suggest reconstruction of the pattern applied in the methodology of history. I assume that the reality to which we refer is of semiotic nature which emerges and develops as part of human communication and therefore offers an opportunity to study its changes. 